\title{
円筒状リニア同期モータの推力特性の改善
}

\author{
正員山口 昌樹 (東京農工大学) 学生員 安藤 善之 (東京農工大学) \\ 正員鹿野快男 (東京農エ大学) 正員小林学 (ブラザーエ業) \\ 正員荻田充二 (神䥔電機)
}

\section{Thrust Characteristics Improvement of a Cylindrical Linear Synchronous Motor}

Masaki Yamaguchi, Member, Yoshiyuki Ando, Student member, Kano Yoshio, Member (Tokyo University of Agriculture and Technology)

Manabu Kobayashi, Member (Brother Industries, Ltd.),

Mitsuji Karita, Member (Shinko Electric Co.,Ltd.)

As a result of attempting the optimization of iron core shape of a cylindrical linear synchronous motor (C-LSM) in which thrust per unit product is large, following matters became clear:

1. The suction force is produced in the stator edge between mover and bearing, since magnetic material is used for a part of the linear bearing. It is one of the error factors in calculating the static thrust characteristics.

2. The maximum static thrust changed 3.7 newtons by the existence of the salient pole of the mover while detent thrust changed only 0.39 newtons. It is proven that the maximum detent thrust does not change by establishing salient pole, and simultaneously the maximum static thrust can be improved $6.7 \%$.

3. The relationship between maximum static thrust and open width of the semienclosed slot is calculated by using FEM. The maximum static thrust of 57.3 newtons can be obtained, and detent thrust / maximum static thrust ratio is made $4 \%$ when the width of the semienclosed slot is made to $1 \mathrm{~mm}$. The calculation is verified in a measerment of a test machine.

4. As the result of measuring the speed control characteristics of the C-LSM, speed error can be supressed to $5 \%$ under the condition of driving speed $80 \mathrm{~mm} / \mathrm{s}$.

キーワード：リニア同期モータ, 円筒状, ディテントカ, 有限要素法, 節点力法, 鉄心

\section{1. まえがき}

円筒状リニア同期モータ (Cylindrical Linear Synchronous Motor, 以下, C-LSM と略す) は, 平板状のリニア同期 そータに比べて 1) 高い推力/体積比を得易い，2）軸対 称形状となるので製作が容易，等といった特長を有して いる。その一方で, 軸のわずかな偏心が支持機構の寿命 を低下させる可能性もある。そのため，平板状 LSM ほ ど産業応用が進んでおらず，開発例も少ないのが現状で ある。一方，LSM の開発においては非励磁時に発生する ディテントカを低減することは重要な課題であり, 今ま でに磁石にテーパをつける方法(1)やポールピッチを調整す る方法(2)等が報告されているが，静推力特性に大きな影響 を及ほす鉄心の形状に関する詳細な検討はそれほど多く
ない。特に，C-LSMではその両端に可動子を支持するべア リングを設けるのが一般的でその全長は長くなり易いが, モータ全長に制約がありかつストロークがある程度必要 であるというような相反する要求仕様が課せられた場合 には，端効果やベアリング材質が推力に与える影響毛無 視できなくなる。そこで，筆者等は節点力法を用いた有 限要菜法 (以下, FEM と略す)により C-LSM の鉄心形 状の最適化を図り，設計した C-LSM を試作してその妥 当性を検証した。本論文では, 試作した C-LSM に関し 以下の事項について述べる。

(1) ベアリング材質の静推力特性への影響

（2）可動子に作用する表面力の可動子突極の有無による 比較

（3）電機子鉄心の形状による静推力特性の比較

(4) 速度制御特性 


\section{2. 售造と磁氮特性}

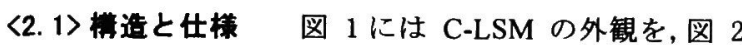
には断面構造を示す(3)。試作した C-LSM は，可動子側 に界磁用磁石が，固定子側に電機子コイルが配置されて いる磁石可動形の LSM である。以後, 可動子と固定子 の中心が一致した位置を変位 $x=0[\mathrm{~mm}]$ として述べる。 可動子には, ラジアル着磁された 2 個の円筒状 $\mathrm{Ne}-\mathrm{Fe}-\mathrm{B}$ 合金磁石（住友特殊金属秼，Neomax-32H，エネルギー積 $\left.239\left[\mathrm{~kJ} / \mathrm{m}^{3}\right]\right)$ が，隣り合う磁石の極性が反対となるよう に配置されている。永久磁石の両端には, その磁束の短 絡を防ぐために非磁性リング（A1）を挿入した。スロッ 卜には三相巻線が施され，スター結線されている。各相 のコイルは, 起磁力の高調波を低減するために分布巻さ れるの一般的であるが，C-LSM の場合構造上分布巻が困 難であるので集中巻とした。支持機構には，ボールリテ 一ナ付きのリニアベアリング（THK物，LMF30）を用い ることにより, 従来円筒状リニアモータで問題となって いた可動子の偏心による特性の劣化を防止している(4)。 可動子の回転を防止するために, 可動子シャフトには溝 を設け，その上をリニアベアリングのボールが往復する ようにした。表 1 には, 試作した C-LSM の仕様を示し た。エアギャップは 1 [mm] でありリニア同期モータの 中では比較的小さい。可動子の長さ $120[\mathrm{~mm}]$ に対して電 機子鉄心の長さは $146[\mathrm{~mm}]$ とその差は 26[mm]しかないが, ストロークを $60( \pm 30)[\mathrm{mm}]$ 得るために, 変位が $\pm 13[\mathrm{~mm}]$ よりも大きくなると可動子はリニアベアリング中に突出 することとなる。駆動速度の目標值は $10 \sim 200[\mathrm{~mm} / \mathrm{s}]$ に選定し，スロットピッチを $16[\mathrm{~mm}]$ ，ポールピッチは その 3 倍の 48 [mm] に一致させた。この結果, 駆動周 波数は $0.1[\mathrm{~Hz}] \sim 2[\mathrm{~Hz}]$ 程度となり鉄損の影響が非常 に小さいと考えられたので, 可動子と電機子の鉄心材料
には一般構造鋼である S15C （最大磁束密度 1.87 [T]） のブロック材を用いた。

〈2. 2〉磁気特性本 C-LSM の磁気回路設計には, 節点力法(5)を用いた非線形 FEM (坿日本総研, JMAGWorks Ver.3.1) により行った。計算には 2 次元軸対称モ デルを用いており，支持機構であるべアリングもモデル 化した。ベアリングは，その材質であるステンレス龬と 磁気特性がほほ同等な一般構造鋼 SS400 のブロック材と 置き換えて全体をモデル化し，可動子とべアリングの間 には $0.04[\mathrm{~mm}]$ のエアギャップを設けた。解析モデルの 要素数は 5219, 節点数は 5482 である。計算条件は, 変 位 $x=0[\mathrm{~mm}]$, 電機子電流 $I_{\mathrm{u}}=-1.2[\mathrm{~A}], I_{\mathrm{v}}=2.4[\mathrm{~A}], I_{\mathrm{w}}=$ $-1.2[\mathrm{~A}]$ とし, また電気角は $\theta=210^{\circ}$ に選定した。計 算機には，Pentium プロセッサを搭載したパソコン (DIGITAL Celebris, GL-2 (DEC)) を用いた。

図 3 には, 試作した C-LSM の磁束密度分布の計算結 果を示す。定格電流において電機子鉄心の最大磁束密度 は 1.84 [T] とほぼ S15C の飽和磁束密度 (1.87[T])に達し ており, 試作した C-LSM の磁路が適切に与えられてい ることが判明した。

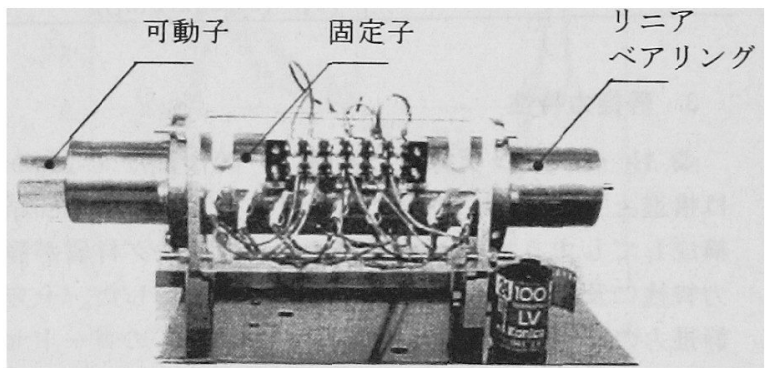

図 1 C-LSM の外観

Fig.1 External view of a C-LSM.

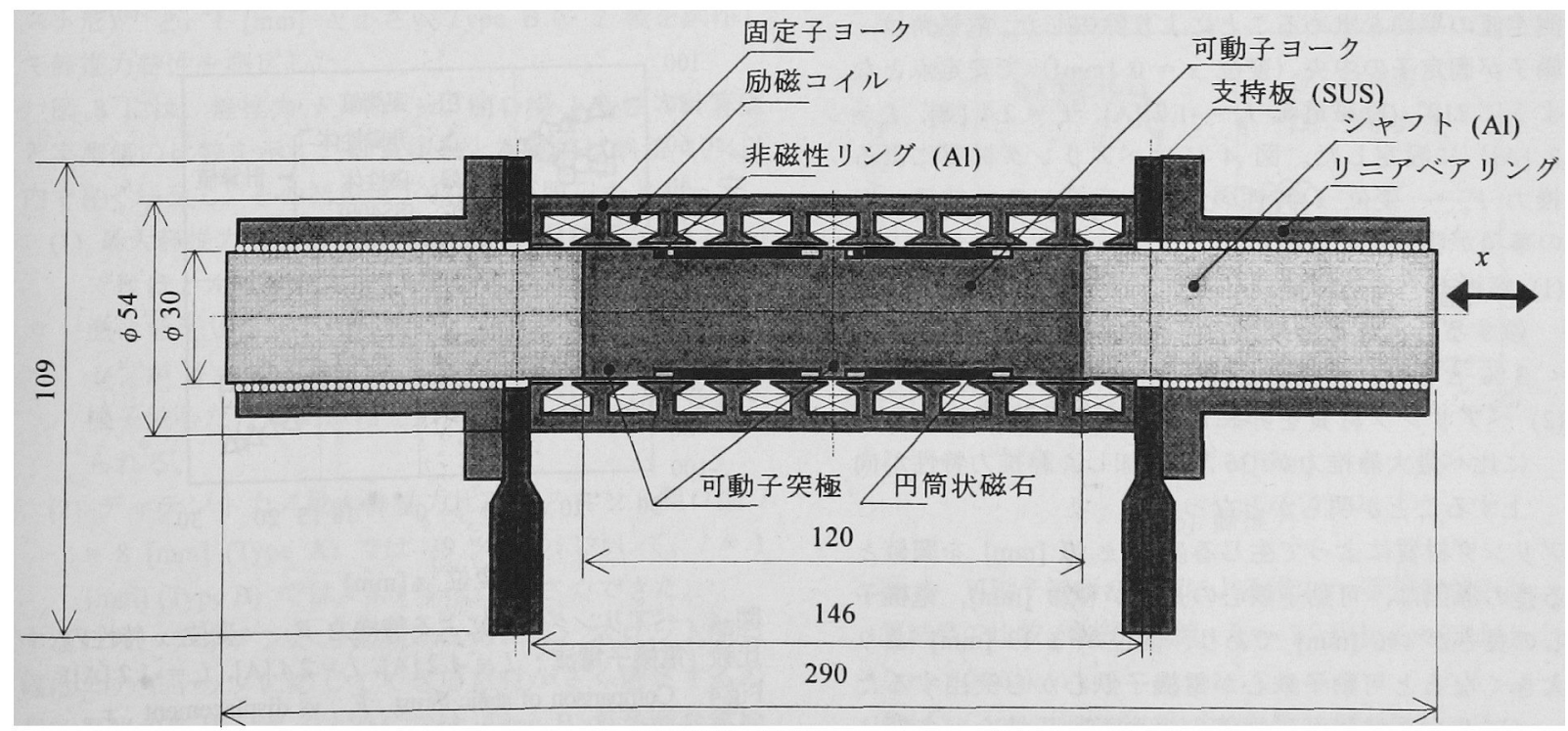

図 2 C-LSM の断面構造（変位 $x=0[\mathrm{~mm}]$, 単位 : $[\mathrm{mm}]$ )

Fig.2 Structure of the C-LSM. 
表 1 試作したC-LSM の仕様

Tablel Specifications of the manufactured C-LSM.

\begin{tabular}{|c|c|c|c|}
\hline 項目 & & 数值 & [単位] \\
\hline 固定子寸法 & & $\phi 54 \times 146$ & {$[\mathrm{~mm}]$} \\
\hline 可動子寸法 & & $\phi 30 \times 120$ & [mm] \\
\hline 質量 & $M$ & 3 & {$[\mathrm{~kg}]$} \\
\hline エアギャップ & $g$ & 1 & [mm] \\
\hline ストローク & $s$ & 60 & [mm] \\
\hline 極数 & $N_{\mathrm{m}}$ & 2 & [無次元] \\
\hline 磁石幅／極ピッチ比 & $h$ & 0.67 & [無次元] \\
\hline ポールピッチ & $\tau$ & 48 & {$[\mathrm{~mm}]$} \\
\hline スロットピッチ & $\tau_{\mathrm{s}}$ & 16 & [mm] \\
\hline スロット深さ & $d_{s}$ & 11 & [mm] \\
\hline スロット開ロ幅 & $l$ & 1 & {$[\mathrm{~mm}]$} \\
\hline 歯幅 & $W_{\mathrm{t}}$ & 5 & {$[\mathrm{~mm}]$} \\
\hline コイル線径 & $d$ & 0.5 & {$[\mathrm{~mm}]$} \\
\hline 占積率 & $\xi$ & 0.54 & [無次元] \\
\hline コイル巻数 & $N$ & 140 & [mm] \\
\hline 定格電流 & $I_{\mathrm{r}}$ & 1.7 & {$[\mathrm{~A}]$} \\
\hline 磁石材料 & & \multirow{2}{*}{\multicolumn{2}{|c|}{$\begin{array}{l}\mathrm{Nd}-\mathrm{Fe}-\mathrm{B} \text { alloy } \\
\left(\text { エネルギー積 } 239\left[\mathrm{~kJ} / \mathrm{m}^{3}\right]\right) \\
\mathrm{S} 15 \mathrm{C} \\
(\text { 最大磁束密度 } B=1.87 \\
[\mathrm{T}], \quad(8.12[\mathrm{kA} / \mathrm{m}]))\end{array}$}} \\
\hline 鉄心材料 & & & \\
\hline
\end{tabular}

\section{3. 静推力特性}

〈3. 1〉ベアリング材質の影霎陚作した C-LSM で は構造上可動子鉄心がベアリングに接触し, 磁気回路を 構成してしまう場合があるので, ベアリング材質が静推 力特性に及ぼす影響を FEM によって解析した。一方, 静推力の測定には引張圧縮両用の 20 [kgf] のロードセル (侏共和電業, LM-20KAM192)を, 変位の測定にはレー ザ変位計 (アンリツ侏，KL137F) を用いた。摩擦力は, 可動子を往復移動させながら静推力を測定し, 同変位で の測定值の平均を求めることにより除去した。電気角は, 可動子が固定子の中央（変位 $x=0[\mathrm{~mm}]$ ）で安定点とな るように $210^{\circ}$ (励磁電流 $I_{\mathrm{u}}=-1.2[\mathrm{~A}], I_{\mathrm{v}}=2.4[\mathrm{~A}], I_{\mathrm{w}}=$ -1.2[A]）に設定した。図 4 にはベアリング材質による 静推力 $F_{\mathrm{s}}$ - 変位 $x$ 特性の比較を示す。その結果, 以 下の事項が明らかとなった。

(1) 解析モデルにおいてベアリング材質を SS400 で近 似すると, 最大静推力の実測値に対する計算誤差は $3 \%$ となり，実測值と計算值はほぼ一致した。

(2) ベアリング材質を非磁性体にすると磁性体の場合 に比べ最大静推力が $36 \%$ 増加し, 静推力特性が向 上することが明らかとなった。

ベアリング材質によって生じる変位 $\pm 13[\mathrm{~mm}]$ を闌值と する差の原因は, 可動子鉄心の長さが 120 [mm], 電機子 鉄心の長さが $146[\mathrm{~mm}]$ であり, 変位が $\pm 13[\mathrm{~mm}]$ より も大きくなると可動子鉄心が電機子鉄心から突出するた め, ベアリング材質が磁性体の場合可動子鉄心との間に
磁気回路が形成されるためだと考えられる。以上のよう に, 試作した C-LSM では可動子長さ, 固定子長さ及びス トロークにこのような固有の関係があるために, ベアリ ング材質が静推力特性に影響を与えることが明らかとな った。よって, 以後の計算では全てベアリング材質を磁 性体 (SS400) として計算を行う。

〈3. 2〉可動子鉄心形状による比较可動子鉄心の表 面に設けた突極がギャップ磁気抵抗を低減する効果があ るか否かを FEMによりシミュレーションしてみる。図 5 には, 可動子の突極の有無による表面力分布の計算結果 の比較を示す。図中の矢印（破線）は, 可動子の表面要 素に作用するカのベクトルの大きさと作用方向を拡大し て示しており，破線の中心が作用点である。

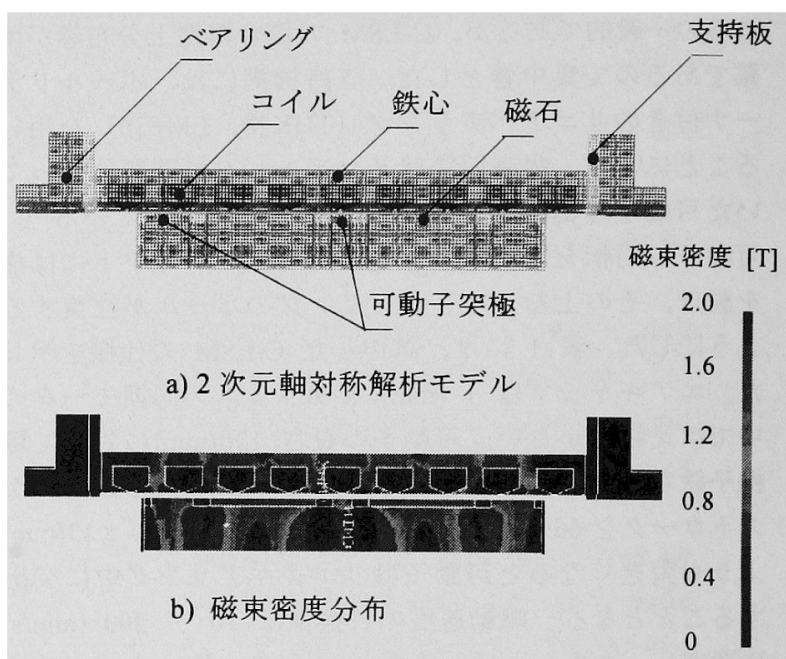

図 3 FEM による磁束密度分布の計算結果 (変位 $x=0$ [mm], 要素数 : 5219 , 節点数 : 5482 , 電機子電流 ; $I_{\mathrm{u}}=-1.2$ [A], $\left.I_{\mathrm{v}}=2.4[\mathrm{~A}], I_{\mathrm{w}}=-1.2[\mathrm{~A}]\right)$

Fig.3 Calculated result of the magnetic flux density by FEM.

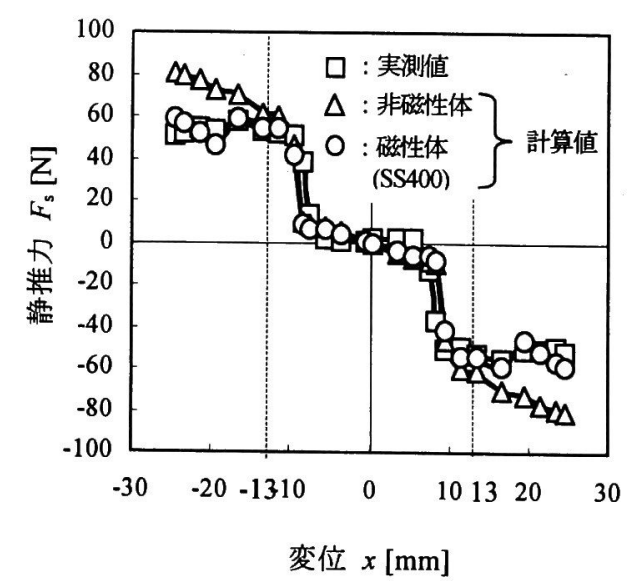

図 4 ベアリング材質による静推力 $F_{\mathrm{s}}$ - 変位 $x$ 特性の 比較 (電機子電流; $I_{\mathrm{u}}=-1.2[\mathrm{~A}], I_{\mathrm{v}}=2.4[\mathrm{~A}], I_{\mathrm{w}}=-1.2[\mathrm{~A}]$ ) Fig.4 Comparison of static thrust, $F_{\mathrm{s}}$, vs displacement, $x$, characteristics by material of a bearing. 
(a)の突極が無い場合には磁束が磁石部分に集中している が, (b)の突極が有る場合には磁石部分だけでなく突極の 部分にも磁束が分布するようになるが，両端と中央の突 極の部分にも磁束が分布するようになるが, 主に垂直力 しか増加しないことが判る。

図 6 には，可動子突極の有無による静推力 $F_{\mathrm{s}}$ 一変位 $x$ 特性の比較を示す。乫極が有る場合には突極が無い場 合と比較して最大ディテントカは変位 $\pm 5.5[\mathrm{~mm}]$ において 0.39[N]增加したが, それでも 1.06[N]しかなかった。一方, 最大静推力は変位士 $17[\mathrm{~mm}]$ において 3.7 [N] ( $6.7 \%)$ 増 加しており,僅かではあるが突極を設けた方が静推力を向 上できることが判った。しかし，突極を設けるには切削加 工数が増えて製作コストがアップする事を考えると，こ の程度の部分的な静推力の增加しか期待できないならば, あえて突極を設けない設計も成り立つであろう。以上の ように, 図 5, 図 6 のいずれの結果も突極の効果が小さ いことで一致し，従来実験による検証が不可能であった “表面力の分布”を節点力法により計算することで視覚 的にも把握できた。

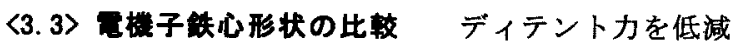
するために, 電機子鉄心のスロット形状に半閉スロット を採用し、ディテントカノ最大静推力比が最小となるス ロット開口幅 $l$ の最適設計を行う。図 7 には, スロット 開口幅をパラメータとした電機子鉄心の形状を示す。解 析に当たり, 鉄心の最大磁束密度 $B_{\text {max }}=1.84[\mathrm{~T}]$ 一定と いう制約条件を設け，磁極の磁束密度がスロット開口幅 で変化しないように磁極片のテーパ角 $\theta_{\mathrm{t}}$, 歯幅 $W_{\mathrm{t}}$ も スロット開口幅 $l$ に応じて変化させた。また, 励磁電流 は $I_{\mathrm{u}}=-1.2[\mathrm{~A}], I_{\mathrm{v}}=2.4[\mathrm{~A}], I_{\mathrm{w}}=-1.2[\mathrm{~A}]$ に設定し, 変位 $\pm 30[\mathrm{~mm}]$ の範囲を計算した。この計算精度を検証するた めに, スロット開口幅が $8[\mathrm{~mm}]$ と大きい Type A (低コ スト形) ${ }^{(6)}$ と, 1 [mm] と小さい Type B の 2 種を試作し て静推力特性を測定した。

図 8 には, 静推力 $F_{\mathrm{s}}$-スロット開口幅 $l$ 特性の計算值 と実測值の比較を示す。計算結果と実測值は誤差 $19 \%$ 以 内で良く一致し，その結果以下の事項が明らかとなった。

(1) 最大静推力の計算值は, スロット開口幅 $l>1[\mathrm{~mm}]$ ではほとんど変化しなかったが， $l<1[\mathrm{~mm}]$ で急 激に低下した。この理由は，本 C-LSM のエアギャ ップが $g=1[\mathrm{~mm}]$ であるために, $l<g$ とすると電 機子鉄心だけで閉磁路を形成してしまうためと考え られる。

(2) ディテントカ/最大静推力比は, スロット開口幅 $l$

$=8[\mathrm{~mm}]$ (Type A) では $39 \%$ \%のに対して, $l=1$ [mm] (Type B) では, $4.0 \%$ まで小さくできた。

すなわち，ディテント力低隇のためには，スロット開口 偪はエアキャャップに応じてできるだけ小さく選定するの が効果的であり，本 C-LSM では Type B が最適な電機 子鉄心開口幅であることが判った。

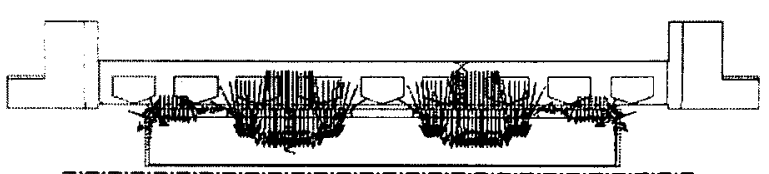

(a) 突極無 $\mathrm{L}$

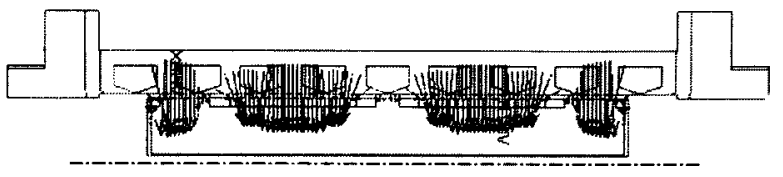

(b) 突極有り

図 5 可動子の突極の有無による表面力分布の計算 結果 (変位 $x=0[\mathrm{~mm}]$, 電機子電流; $I_{\mathrm{u}}=-1.2[\mathrm{~A}]$, $\left.I_{\mathrm{v}}=2.4[\mathrm{~A}], I_{\mathrm{w}}=-1.2[\mathrm{~A}]\right)$

Fig.5 Comparison of the surface force by presence of the salient poles on the mover.

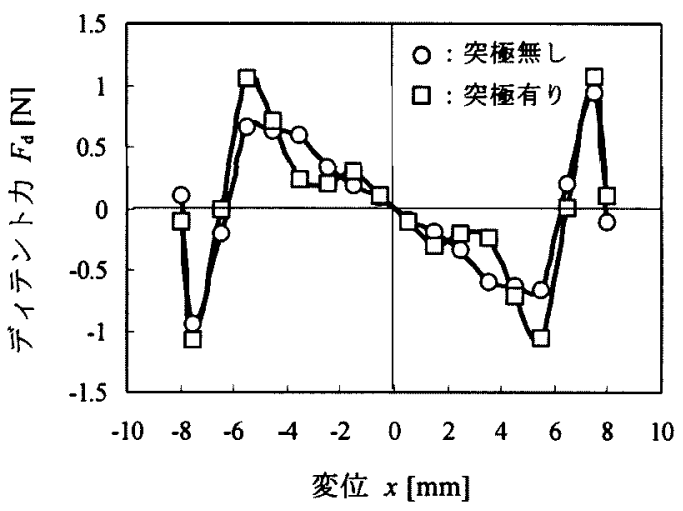

(a) ディテントカ

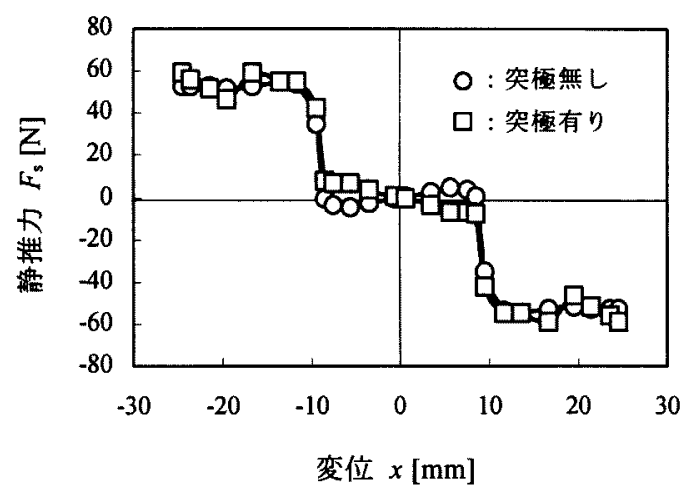

(b) 静推力

図 6 可動子突極の有無による推力 一変位特性の計 算結果の比較 (電機子電流; $I_{\mathrm{u}}=-1.2[\mathrm{~A}], I_{\mathrm{v}}=2.4[\mathrm{~A}]$, $\left.I_{\mathrm{w}}=-1.2[\mathrm{~A}]\right)$

Fig.6 Comparison of static thrust, $F_{\mathrm{s}}$, vs displacement, $x$, characteristics by presence of salient poles on the mover. 


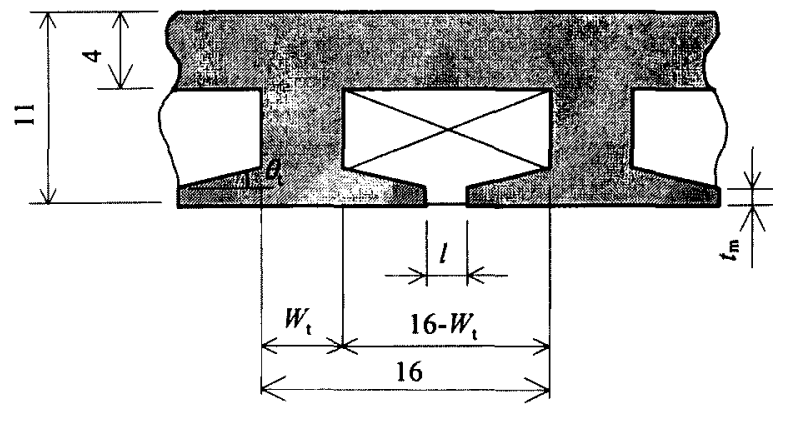

\begin{tabular}{|c|c|c|c|c|c|}
\hline \multirow{2}{*}{ 項 目 } & & & 法 & & \\
\hline & & \multicolumn{2}{|c|}{ Type A } & \multicolumn{2}{|c|}{ Type B } \\
\hline スロット開口幅 & $t$ & 8 & {$[\mathrm{~mm}]$} & 1 & {$[\mathrm{~mm}]$} \\
\hline 磁極片テーバ角 & $\theta_{1}$ & 0 & $\left.l^{\circ} \quad\right]$ & 22.3 & {$\left[\begin{array}{ll}0^{\circ} & ]\end{array}\right.$} \\
\hline 㑶塌 & $W_{1}$ & 4 & [mm] & 5 & {$[\mathrm{~mm}]$} \\
\hline 磁極片厚さ & $t_{\mathrm{m}}$ & 1 & [mm] & 0.3 & [mm] \\
\hline
\end{tabular}

図 7 C-LSM の電機子鉄心形状 (単位 $[\mathrm{mm}]$ )

Fig.7 Shape of the armature core of the C-LSM.

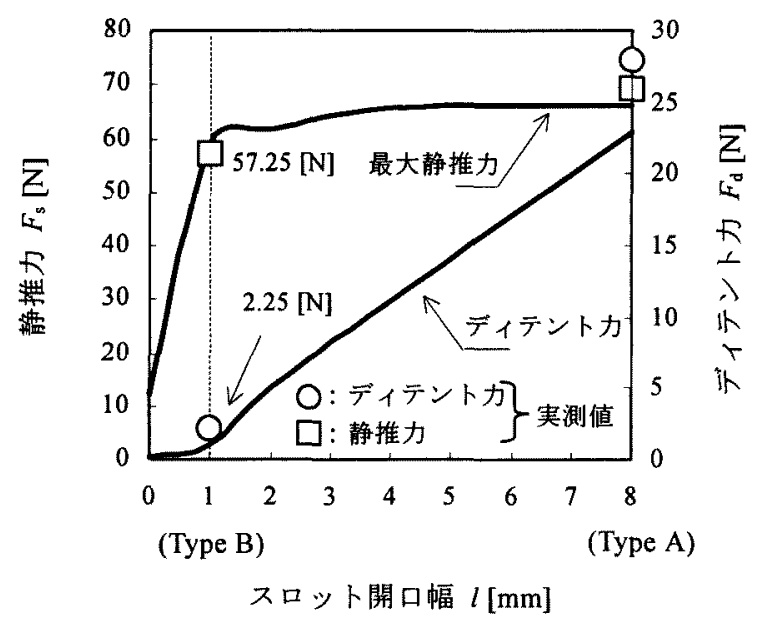

図 8 静推力 $F_{\mathrm{s}}$ 一スロット開口幅 $l$ 特性の計算值と 実測値の比較 (電機子電流; $I_{\mathrm{u}}=-1.2[\mathrm{~A}], I_{\mathrm{v}}=2.4[\mathrm{~A}]$, $\left.I_{\mathrm{w}}=-1.2[\mathrm{~A}]\right)$

Fig.8 Comparison of static thrust, $F_{s}$, vs open width of slot, $l$, characteristics.

\section{4. 䀲期特性}

静推力に対してディテントカが無視できる程度に小さ くなるようなモータを設計し，負荷角の変動を小さくす れば，同期モータも直流モータと同様な簡単な制御系で 駆動することが可能となる。図 9 には, C-LSM の速度 制御システムを示す。制御はドライバ(サーボランド侏, SVDM6-A）を用いたフィードバック制御によって行った。 速度制御量は変位信号を微分することで得ており, C-LSM はこの制御量とドライバで設定した目標値との偏差に応 じて PWM 駆動される。使用したエンコーダ (日本ヒュ ーレットパッカード㑣, HEDS9200 300LPI) の分解能は $300[\mathrm{PPI}](80[\mu \mathrm{m}]$ ピッチ)となっており，エンコーダの出
カパルス数はドライバ内で 4 进倍されている。速度の目 標值はドライバから出力される加速度信号を D/A 変換 器 (サーボランド侏, MB-SV2) によってアナログ信号 に変換して，デジタルレコーダ（横河電機㑣，AR1200） で稹分演算して記録した。制御ゲイン $(d x / d t)$ の調整は 限界感度法により行った(7)。

図 10 には, C-LSM を設定速度 $80[\mathrm{~mm} / \mathrm{s}]$, 変位 \pm 20 [mm] で往復眮動させたときの速度制御特性の測定結果 を示す。電機子形状 TypeA では, ディテントカが最大静 推力の 36\%にも達しているためにスロットピッチに一致 した速度変動が锶測され速度偏差は最大で 37\%に達した が, 電機子形状 TypeB では, ディテント力／最大静推力 比を 4\%まで小さくできたために安定点付近での推力の脈 動がほとんど無くなり，同期モータにおいても簡単な PI 制御のみで駆動速度 $80[\mathrm{~mm} / \mathrm{s}]$ における速度偏差を $5 \%$ 以 内にまで小さくすることができた。

ドライバ（サーボランド(株)、SVDM6-A)

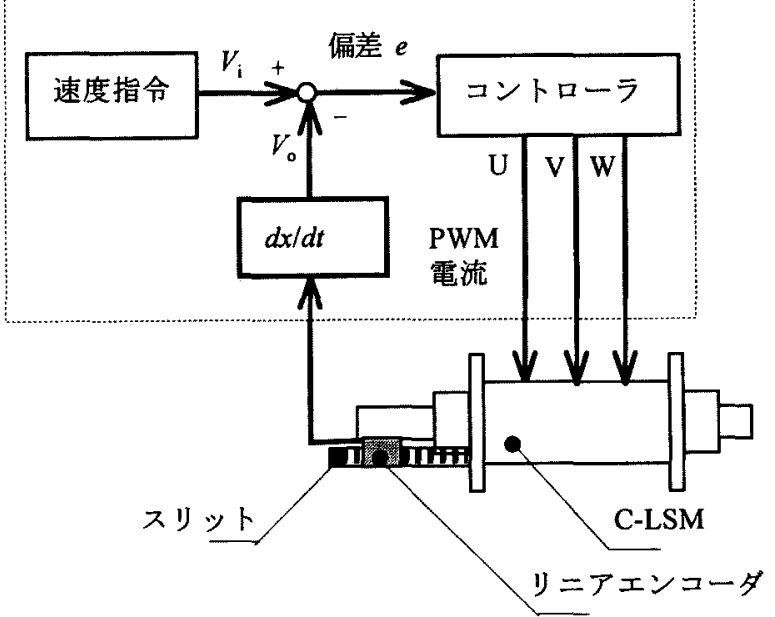

図 9 C-LSM の速度制御システム

Fig.9 Velocity control system of a C-LSM.

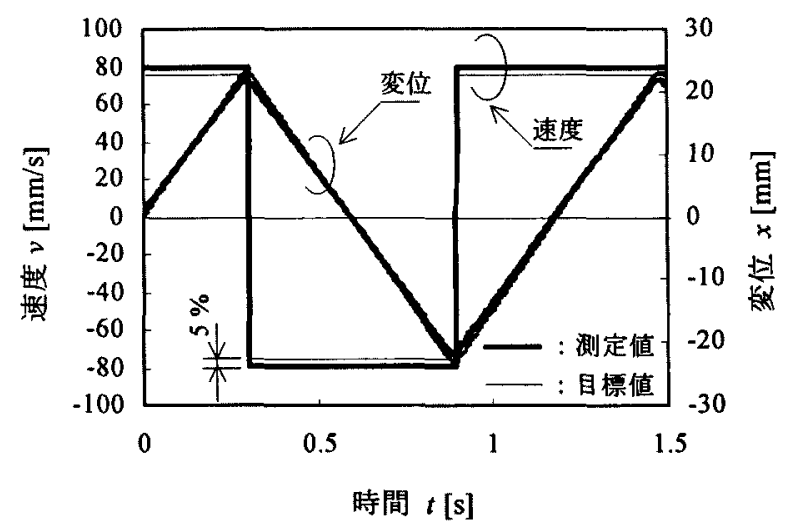

図 10 速度制御特性 $\left(V_{\mathrm{i}}=80[\mathrm{~mm} / \mathrm{s}]\right)$

Fig. 10 Velocity control characteristics. 


\section{5. 哧詅}

筆者らは, 体積 $\phi 54 \times 146\left[\mathrm{~mm}^{2}\right]$ で, 最大静推力 $57.3[\mathrm{~N}]$, 最大ディテントカがわずか $2.3[\mathrm{~N}]$ の円筒状リニア同期 モータを試作することができた。本論文で明らかとなっ た事項をまとめると，以下のようになる。

(1) 支持機構に用いたリニアベアリングの一部が磁性 材料であるために固定子端部で可動子とベアリングとの 間に吸引力が作用し，それが静推力特性の計算誤差要因 となっていることを示した。

(2) 可動子の突極の有無により, 最大静推力は $3.7[\mathrm{~N}]$ 変化したのに対し, 最大ディテントカは 0.1 [N] しか変 化しなかった。つまり，突極を設けることによって最大 ディテント力はほとんど変化せず, 最大静推力を $6.7 \%$ 向上できることが判った。

(3) 半閉スロットの開ロ幅と静推力との関係を FEM を用いて計算した結果，エアギャップが 1 [mm] のとき スロット開ロ幅を 1 [mm] まで小さくすれば, 最大静推 力は $57.3[\mathrm{~N}]$ が得られ, かつディテントカ/静推力比を $4.0 \%$ まで小さくできることが判明し, 試作により本計 算の妥当性を検証した。

(4) C-LSM のディテントカを低減できた結果, 簡単な PI 制御のみで駆動速度 $80[\mathrm{~mm} / \mathrm{s}]$ における速度偏差を $37 \%$ から $5 \%$ \%内まで小さくすることができた。

最後に円筒状 $\mathrm{Ne}-\mathrm{Fe}$-B 合金磁石をご提供頂いた住友特 殊金属株式会社 開発本部研究開発企画室 主席研究員 中西 昭男博士, C-LSM の駆動プログラムの構築にご 協力頂いたサーボランド株式会社 代表取締役 細萓 宏明 氏, 営業部部長 細亘 和雄 氏及び実験に協力された本学 工学部電子情報工学科 4 年 松木 恵子 氏に感謝の意を 表す次第である。

(平成 11 年 2 月 19 日受付, 平成 11 年 7 月 14 日再受付)

\section{文献}

(1) 水野 勉, 山田一：「永久磁石形リニア同期モータの

静推力特性」, 電学論, D-111，6，482-488 (1991)

(2) 鳥居 肃, 吉村武, 和多田雅哉, 海老原大樹:「リ ニア同期モータのディテントカを低减する設計法」,

電学論, D-117，4，487-492 (1997)

（3）安藤善之, 松木恵子, 山口昌樹, 鹿野快男, 小 林 学, 荻田 充二：「上肢補助装置に用いる円筒状り ニア同期モータの静推力特性」, 電気学会リニアドラ イブ研資，LD-98-72，13-18 (1998)

(4) 電気学会搬送用リニアメカニズム調査専門委員会 : 「搬送用リニアメカニズムの実用化動向と将来展望」, 電気学会技術報告, 第 657 号, 5-7 (1997)

（5）亀有 昭久:「節点力法による電磁力解析」, 静止機回 転機合同研究会資料, SA-93-11，RM-93-49，95-104 (1993)

(6) YAMAGUCHI Masaki, MANABE Katsuyuki, ANDO Yoshiyuki, KANO Yoshio and KOBAYASHI,
Manabu : "Cylindrical Linear Synchronous Motor for Forearm Support Apparatus", LDIA'98 Tokyo, AP-4, 426-429 (1998)

(7) 稲葉 博, 西田 直矩, 田村 捷利, 渡辺 嘉二郎 : 「現 代制御工学概論」，196-198，オーム社(1980)

山口昌樹 (正員) 1963 年 2 月 28 日生。1987 年信

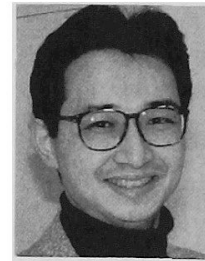
州大学大学院工学研究科修士課程修了。 同年ブラザー工業森入社, 中央研究所に 配属。1995 年より東京農工 助手。工 学博士。リニアモータ・センサを研究の 中心に据えて医用電子工学の研究に従事。 IEEE, 日本応用磁気学会, 日本 ME 学 会, ライフサポート学会などの会員。

安藤善之 (学生員) 1972 年 7 月 18 日生。1997 年

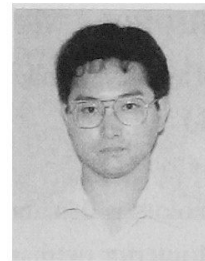
東京農工大学工学部電子情報工学科卒業。 同年 4 月より同大学院生物システム応 用科学研究科博士前期課程に在学。福祉 機器への応用を踏まえたリニア電磁アク チュエータの研究に従事、1999 年 4 月 より川崎重工業㑣に入社予定。日本応用 磁気学会の会員。

鹿野快男 (正員) 1938 年 8 月 4 日生。1960 年明

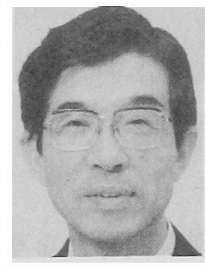
治大学大学院博士課程修了。同年東京農 工大学工学部 助手。現在, 同大学院生 物システム応用科学研究科 教授。工学 博士。主として磁気回路, 電磁アクチュ エータ及び農業, 土木, 生物に関する応 用計測の研究に従事。応用物理学会, 農 業機械学会, 日本生物環境調節学会など の会員。

小林 学 (正員) 1965 年 2 月 13 日生。1990 年信州

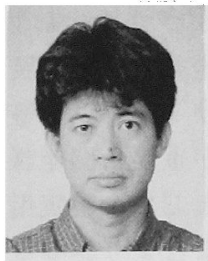
大学大学院工学研究科修士課程修了。同 年ブラザー工業侏入社。1997 年信州大 学大学院博士課程修了。工学博士。生産 設備に応用するリニアモータの開発に従 事。日本応用磁気学会, 日本人工臟器学 会などの会員。

获田 充二 (正員) 1944 年 7 月 26 日生。1968 年 3 月

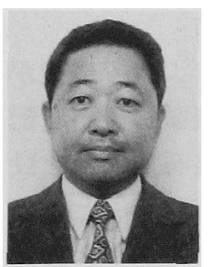
岡山大学工学部電気工学科卒業。同年神 鋼電機侏入社。開発本部商品開発部勤務。 リニアモータ，サーボアクチュエータお よび応用製品の研究・開発に従事。現在 同部主席研究員。平成 10 年度東京農工 大学客員教授。工学博士。日本機械学会, 精密工学会などの会員。 